\title{
Growth Performance, Haematological Parameters, Intestinal Microbiology, and Carcass Characteristics of Broiler Chickens Fed Two-Stage Fermented Cassava Pulp during Finishing Phase
}

\author{
S. Sugiharto*, T. Yudiarti, \& I. Isroli \\ Department of Animal Science, Faculty of Animal and Agricultural Sciences, Diponegoro University \\ Kompl. drh. R. Soejono Koesoemowardojo, Tembalang Semarang 50275, Indonesia \\ ${ }^{*}$ Corresponding author: sgh_undip@yahoo.co.id \\ (Received 07-12-2018; Revised 11-01-2019; Accepted 07-02-2019)
}

\begin{abstract}
This study aimed to investigate the effect of two-stage fermented cassava pulp (FCP) on growth, blood parameters, intestinal microbiology and carcass characteristics of broilers. Two hundreds Lohmann broiler chicks were used from days 22 to 38 and allotted to CONT (maize-soybean-mealbased finisher diet), FCP-10 (finisher diet containing 10\% FCP), FCP-15 (15\% FCP) and FCP-20 (20\% FCP). FCP was included into finisher diet at the expense of maize. On day 38 , one bird per replicate was blood sampled and slaughtered. Ileal and caecal digesta and duodenal, jejunal and ileal segments were obtained for intestinal microbiology and villi height measurements. Breast muscle was obtained for meat colour determination. FCP-10 had a higher $(\mathrm{p} \leq 0.05)$ body weight gain than CONT. Feed intake was highest $(\mathrm{p} \leq 0.05)$ in FCP-15 and the lowest $(\mathrm{p} \leq 0.05)$ in CONT. Feed conversion ratio was lowest and highest in FCP-10 and FCP-15, respectively ( $\mathrm{p} \leq 0.05)$. FCP-20 had a lower $(\mathrm{p} \leq 0.05)$ abdominal fat than CONT and FCP-10. CONT had lower $(\mathrm{p} \leq 0.05)$ serum total triglycerides than FCP-15 and FCP-20. Duodenal villi height for FCP-20 was higher $(p \leq 0.05)$ than that for CONT and FCP-15. The ileal villi height for FCP-20 was lower $(\mathrm{p} \leq 0.05)$ than that for CONT and FCP-15. The wings relative weight was higher $(\mathrm{p} \leq 0.05)$ in FCP-20 than in FCP-10 and FCP-15. FCP-15 and FCP-20 had higher $(p \leq 0.05) L^{*}$ (lightness) values than CONT. In conclusion, feeding two-stage FCP up to $20 \%$ had no deleterious effect on growth, haematological parameters, intestinal microbiology and carcass characteristics. Feeding two-stage FCP at a level of $20 \%$ reduced the abdominal fat content and increased duodenal villi height of broilers.
\end{abstract}

\section{Keywords: agro-industrial by-product; Bacillus subtilis; broiler; Chrysonilia crassa; two-stage fermentation}

\section{INTRODUCTION}

Broiler industry has been growing substantially in Indonesia over the last three decades. The rapid expansion of the broiler industry, however, is not parallel with the increased local supply of broiler feed ingredients. This condition may insist the broiler feed mills to import feedstuffs especially maize, which is the most common energy source and major feed ingredient for broilers (Utomo, 2012). To decrease the import dependency for maize, it is crucial to use locally available feedstuffs as alternative feed ingredients for broilers (Reyes et al., 2018). Cassava pulp, which is a waste product of cassava-processing industry and rich in energy, has recently been used as dietary ingredient for broiler. However, the use of such ingredient is often limited by the high and low contents of fibre and protein, respectively. In the study of Khempaka et al. (2009), dietary inclusion of dried cassava pulp above $8 \%$ compromised the growth performance and nutrient digestibility of broilers. To improve its nutritive values and increase inclusion levels in the rations, cassava pulp can be fermented prior to feeding to broilers (Huu \& Khammeng, 2014; Khempaka et al., 2014; Sugiharto et al., 2017a). Khempaka et al. (2014) showed that fermentation with Aspergillus oryzae increased the inclusion level of cassava pulp up to $16 \%$ in diets without impairing the performance of birds (fermented cassava pulp [FCP] contained 12.5\% crude protein and $11.2 \%$ crude fibre, as-dry basis). In contrast, our recent work showed that dietary inclusion of $16 \%$ of cassava pulp fermented with Acremonium charticola (FCP contained $8.50 \%$ crude protein and $20.8 \%$ crude fibre) alleviated the final body weight (BW) and increased feed conversion ratio (FCR) of broilers as compared to control (Sugiharto et al., 2017a). Several factors may explain this discrepancy, one of which is the nutritional qualities of the FCP used during the study.

Recently, there has been a growing interest to produce fermented feeds for poultry through two-stage fermentation method (Shi et al., 2017). Compared to a single-stage, two-stage fermentation may produce better nutritional qualities of the substrates. Weng \& Chen (2011) reported that two-step fermentation with Rhizopus oligosporus followed by Bacillus subti- 
lis produced a higher protein content in soybean than fermentation with single starter culture of $B$. sublitis. Previously, we fermented rice bran with a fungus Chrysonilia crassa, and found that fermentation decreased crude fibre, but did not affect the crude protein content of rice bran (Sugiharto et al., 2017b). Considering the aforementioned study and the protein-enhancing effect of B. subtilis during fermentation (Weng \& Chen, 2011; Wongputtisin et al., 2014), fermentation in advance with Ch. crassa followed with $B$. subtilis seemed to be beneficial in decreasing and increasing the fibre and protein contents of cassava pulp, respectively.

With the removal of antibiotic growth promoters (AGP) from broiler feed, nutritionists are now searching for alternatives that can control pathogenic microorganisms and promote growth rate of broilers. Among the alternatives, fermented feed has attracted considerable interest as a substitute for AGP (Sugiharto \& Ranjitkar, 2019). In this respect, two-stage fermentation of cassava pulp using Ch. crassa and B. subtilis may be expected not only to improve the nutritional qualities of cassava pulp, but also to produce functional feed ingredients that can elicit health and growth promoting effects on broilers as was exhibited by AGP. To best of our knowledge, application of the two-stage FCP as a functional feed ingredient in broiler rations has never been documented. The aim of the present study was therefore to investigate the effect of two-stage FCP on growth performance, haematological parameters, intestinal microbiology and carcass characteristics of broiler chickens.

\section{MATERIALS AND METHODS}

\section{Preparation of Starter Cultures}

The preparation of fungal starter cultures was adopted from Sugiharto et al. (2017b) with few modifications. The inoculum of Ch. crassa was prepared by rejuvenating the fungal stock culture (maintained on a potato-dextrose-agar [PDA; Merck KGaA, Darmstadt, Germany] and stored at $4^{\circ} \mathrm{C}$ ) on PDA medium with chloramphenicol. Following the aerobic incubation at $38^{\circ} \mathrm{C}$ for 48 hours, the fungal mycelia was dislodged from the PDA and diluted in $200 \mathrm{~mL}$ of sterile distilled water. To make the fungal starter culture, the suspension of fungal mycelia was used for inoculating of 200 $\mathrm{g}$ of sterilized dry cassava pulp (87.5\% dry matter). The fungus and dry cassava were then thoroughly mixed. Following aerobic incubation at room temperature for 4 days, enumeration of the starter culture was conducted according to the colony counting method. The starter cultures made was further used for fermenting the cassava pulp. B. subtilis was provided by PT. Bayer Indonesia (Jakarta, Indonesia). It was in the form of concentrate and contained minimum $10^{10}$ spores/g.

\section{Preparation of Two-Stage Fermented Cassava Pulp}

The sterilized dry cassava pulp (10 kg) was soaked with sterile water $(1: 1)$ in order to obtain the water content of $c a .40 \%$ in the substrates. The substrate was inoculated with $110 \mathrm{~g} / \mathrm{kg}$ culture of Ch. crassa $(3.6 \times$
$10^{10} \mathrm{cfu} / \mathrm{g}$ ) and $41 \mathrm{~g} / \mathrm{kg}$ urea, and mixed thoroughly (Sugiharto et al., 2017a). The cassava pulp was then incubated aerobically in the plastic bucket for 4 days and turned every 2 days. Following a 4-day incubation with Ch. crassa, cassava pulp was inoculated with $1 \mathrm{mg} / \mathrm{g}$ Bacillus subtilis and incubated for 2 days. The FCP was sundried before use for the in vivo experiment. Data regarding the proximate compositions (AOAC, 1995) of cassava pulp before and after the fermentation are shown in Table 1.

\section{In Vivo Experiment}

A total of 200 unsexed Lohmann MB-202 day-oldchicks (BW: $36.0 \pm 1.07 \mathrm{~g}$, means \pm standard deviation) purchased from a local hatchery were raised in an open-sided broiler house for 38 days. From day 0 to 21 the chicks were raised on starter diet (Table 2). At day 22 the chicks (BW: $392 \pm 4.10 \mathrm{~g}$ ) were allotted to one of four treatment diets, including CONT (maize-soybeanmeal-based finisher diet), FCP-10 (finisher diet containing 10\% FCP), FCP-15 (finisher diet containing 15\% FCP) and FCP-20 (finisher diet containing 20\% FCP). Thus, there were 50 chicks per treatment (5 replicates/ pens of 10 chicks). The treatment/finisher diets were formulated to be isonitrogenous and isocaloric and met the Indonesian National Standards for Broiler Feed (SNI, 2006) (Table 3). The starter and finisher diets were provided ad libitum in mash form for the entire study period. The chicks also had free access to water throughout the experiment. The birds were vaccinated with Newcastle disease virus (NDV) vaccine on days 0 and 18 by spraying and drinking water, respectively. The BW gain, feed consumption and feed conversion ratio (FCR) were determined on days 28 and 38 .

On day 38 , one chick from each pen was randomly sampled. Blood was taken from the bird's wing veins of the sample chickens, and then collected in vacutainers containing ethylene diamine tetra acetic acid for complete blood counts analysis. The rest of the blood was placed in vacutainers without anticoagulant to produce serum (for the determination of antibody titer and serum biochemistry). The same chicks as blood sampled were sacrificed (by neck cut), de-feathered and eviscerated. For the measurements of villi height, the pieces (each about $2 \mathrm{~cm}$ ) of duodenal, jejunal and

Table 1. Chemical compositions of unfermented and fermented cassava pulp

\begin{tabular}{lcc}
\hline $\begin{array}{l}\text { Compositions (\%, as dry-basis, } \\
\quad \text { unless otherwise noted) }\end{array}$ & UCP & FCP \\
\hline Moisture & 13.1 & 18.1 \\
Crude protein & 2.11 & 4.93 \\
Crude fat & 0.14 & 1.19 \\
Crude fibre & 12.0 & 9.73 \\
Ash & 3.28 & 3.22 \\
Metabolizable energy $(\mathrm{kcal} / \mathrm{kg})^{1}$ & 3,116 & 3,246 \\
\hline
\end{tabular}

Note: ${ }^{1}$ Metabolizable energy was calculated based on formula (Bolton, 1967) as follow: $40.81\{0.87$ [crude protein +2.25 crude fat + nitrogen-free extract] +2.5$\}$

UCP: unfermented cassava pulp; FCP: fermented cassava pulp 
Table 2. Ingredients and chemical compositions of starter diet (days 0-21)

\begin{tabular}{lc}
\hline Ingredients & $\begin{array}{c}\text { Composition } \\
(\%, \text { as fed-basis })\end{array}$ \\
\hline Maize & 45.5 \\
Soybean meal & 17.0 \\
Wheat flour & 10.0 \\
Bread flour & 5.00 \\
Rice bran & 4.45 \\
Crude palm oil & 3.50 \\
Corn gluten meal & 3.60 \\
Distiller dried grains & 3.00 \\
Meat bone meal & 2.80 \\
Chicken feather meal & 2.00 \\
Bone meal & 1.50 \\
Lysine & 0.55 \\
Methionine & 0.37 \\
L-threonine & 0.08 \\
Salt & 0.15 \\
Premix ${ }^{1}$ & 0.50 \\
Analyzed composition: & \\
$\quad$ Dry matter & 87.5 \\
Crude protein & 21.7 \\
Crude fibre & 7.63 \\
\hline
\end{tabular}

Note: ${ }^{1}$ Premix contained (per kg of diet) of Ca 2.250 g, P 0.625 g, Fe 3.570 $\mathrm{mg}$, Cu $0.640 \mathrm{mg}$, Mn $5.285 \mathrm{mg}$, Zn $0.003 \mathrm{mg}$, Co $0.001 \mathrm{mg}$, Se $0.013 \mathrm{mg}$, I $0.016 \mathrm{mg}$, vitamin A $375 \mathrm{IU}$, vitamin D $150 \mathrm{IU}$, vitamin E $0.080 \mathrm{mg}$

${ }^{2}$ Metabolizable energy was calculated on the basis of formula (Bolton, 1967) as follow: $40.81\{0.87$ [crude protein +2.25 crude fat + nitrogen-free extract] + 2.5\}

ileal segments were obtained and placed in 10\% neutral formalin buffer solution (Leica Biosystems Richmond, Inc., Richmond, USA). For the enumerations of selected intestinal bacteria, digesta were obtained from ileum and caecum by gently squeezing into the sterile sample bottles. The internal organs and commercial portions of broilers were obtained and weighed. The skinless breast muscles were then obtained for the measurement of meat colour.

The complete blood cell counts of broilers were analysed using a hematology analyzer according to manufacturer's protocols (Prima Fully-auto Hematology Analyzer, PT. Prima Alkesindo Nusantara, Jakarta, Indonesia). The histological analyses were conducted by preparing $5 \mu \mathrm{m}$ slices of duodenum, jejunum or ileum and staining them using haematoxylin and eosin. The measurements of villus height of each intestinal segment were performed using an optical microscope fitted with a digital camera (Leica Microsystems $\mathrm{GmbH}$, Wetzlar, Germany). The counts of bacteria in ileum and caecum of broiler chickens were determined according to Sugiharto et al. (2017b) with few modifications. Total coliform and lactose-negative enterobacteria were enumerated on MacConkey agar (Merck KGaA, Darmstadt, Germany) as red and colourless colonies, respectively, after aerobic incubation at $38^{\circ} \mathrm{C}$ for 24 hours. The sum of coliform and lactose-negative enterobacteria was considered as enterobacteria. The enumeration of lactic
Table 3. Ingredients and chemical composition of finisher diet (day 22-38)

\begin{tabular}{|c|c|c|c|c|}
\hline \multirow[t]{2}{*}{ Ingredients } & \multicolumn{4}{|c|}{$\begin{array}{c}\text { Treatment groups (\%, as fed-basis, } \\
\text { unless otherwise noted) }\end{array}$} \\
\hline & CONT & FCP-10 & FCP-15 & FCP-20 \\
\hline Maize & 64.0 & 54.0 & 49.0 & 44.0 \\
\hline Soybean meal & 20.0 & 20.1 & 20.1 & 20.0 \\
\hline Poultry meat meal & 10.7 & 10.9 & 10.9 & 11.0 \\
\hline Rice & 3.00 & 1.70 & 1.00 & 0.70 \\
\hline Crude coconut oil & 1.00 & 2.00 & 2.70 & 3.00 \\
\hline $\mathrm{FCP}$ & - & 10.0 & 15.0 & 20.0 \\
\hline Methionine & 0.30 & 0.30 & 0.30 & 0.30 \\
\hline Lysine & 0.20 & 0.20 & 0.20 & 0.20 \\
\hline Dicalcium phosphate & 0.30 & 0.30 & 0.30 & 0.30 \\
\hline Premix $^{1}$ & 0.50 & 0.50 & 0.50 & 0.50 \\
\hline \multicolumn{5}{|c|}{ Calculated composition: } \\
\hline $\begin{array}{l}\text { Metabolizable } \\
\text { energy }(\mathrm{kcal} / \mathrm{kg})^{2}\end{array}$ & 3,030 & 3,030 & 3,030 & 3,030 \\
\hline Crude protein & 20.0 & 20.0 & 20.0 & 20.0 \\
\hline Crude fibre & 5.10 & 6.60 & 7.30 & 8.10 \\
\hline Methionine & 0.70 & 0.70 & 0.70 & 0.70 \\
\hline Lysine & 1.40 & 1.40 & 1.40 & 1.40 \\
\hline $\mathrm{Ca}$ & 1.00 & 1.00 & 1.00 & 1.00 \\
\hline $\mathrm{P}$ & 0.70 & 0.70 & 0.70 & 0.70 \\
\hline \multicolumn{5}{|l|}{ Analyzed composition } \\
\hline Dry matter & 87.7 & 85.1 & 85.3 & 85.5 \\
\hline Crude protein & 22.1 & 21.2 & 20.0 & 20.2 \\
\hline Crude fibre & 8.22 & 7.81 & 9.73 & 8.94 \\
\hline
\end{tabular}

Note: ${ }^{1}$ Premix contained (per kg of diet) of Ca $2.250 \mathrm{~g}, \mathrm{P} 0.625 \mathrm{~g}$, Fe 3.570 $\mathrm{mg}$, Cu $0.640 \mathrm{mg}$, Mn $5.285 \mathrm{mg}$, Zn $0.003 \mathrm{mg}$, Co $0.001 \mathrm{mg}$, Se $0.013 \mathrm{mg}$, I $0.016 \mathrm{mg}$, vitamin A $375 \mathrm{IU}$, vitamin D $150 \mathrm{IU}$, vitamin E $0.080 \mathrm{mg}$

${ }^{2}$ Metabolizable energy was calculated on the basis of formula (Bolton, 1967) as follow: $40.81\{0.87$ [crude protein +2.25 crude fat + nitrogen-free extract $]+2.5\}$

acid bacteria (LAB) colonies was performed on de Man, Rogosa and Sharpe agar (MRS; Merck KGaA) following anaerobic incubation at $38^{\circ} \mathrm{C}$ for 48 hours. The haemagglutination inhibition (HI) test (Villegas, 1987) was conducted to determine serum antibody titers against NDV. The antibody titers were presented as geometric mean titers $(\log 2)$. The determinations of serum levels of total triglyceride, total cholesterol, high-density lipoprotein (HDL) cholesterol, low density lipoprotein (LDL) cholesterol, uric acid and creatinine were performed based on the enzymatic colorimetric/colour methods. The serum levels of total protein, albumin, alanine aminotransferase (ALT) and aspartate aminotransferase (AST) were measured on the basis of spectrophotometric/photometric tests. The values of globulin were determined based on the difference between total protein and albumin in serum. These aforementioned serum biochemical analyses were conducted using kits (DiaSys Diagnostic System GmbH, Holzheim, Germany) following the manufacturer's protocols. The colour of meat was determined using digital colour meter in Mac OS X (set to CIE Lab), and presented as L* (lightness), a* (redness) and $b^{*}$ (yellowness) values. 
Data collected were subjected to analysis of variance using the General Linear Models Procedure in SAS (SAS Inst. Inc., Cary, NC, USA). Results are expressed as least square means (LSMEANS) and standard error (SE). Further analysis with Duncan's multiple-range test was conducted when significant differences $(P \leq 0.05)$ existed among the treatment groups.

\section{RESULTS}

\section{Performances and Internal Organs of Broilers}

On days 22-28, birds fed finisher diets containing FCP had higher $(\mathrm{p} \leq 0.05)$ BW gain than those fed the control diet (Table 4). At days 22-38, FCP-10 fed birds had higher $(\mathrm{p} \leq 0.05) \mathrm{BW}$ gain than CONT birds. During the periods of days 29-38 and 22-38, the highest feed intake $(p \leq 0.05)$ was found in FCP-15 and the lowest was in CONT. The FCR were lower $(p \leq 0.05)$ in CONT and FCP-10 than in FCP-15 and FCP-20 during the period of days 29-38. During the period of days 22-38, the lowest FCR $(p \leq 0.05)$ was found in FCP-10 and the highest FCR $(p \leq 0.05)$ was found in FCP-15.

FCP-20 birds had a lower $(\mathrm{p} \leq 0.05)$ relative weight of abdominal fat pad than the CONT and the FCP-10 birds
(Table 4). There was no significant differences in the other internal organs of broilers.

\section{Blood Parameters of Broilers}

The blood cell counts and serum antibody and biochemical parameters are presented in Table 5. In general, there was no significant effect of the dietary treatments on the measured parameters. The birds in CONT group had lower $(\mathrm{p} \leq 0.05)$ total triglycerides in the serum than those in FCP-15 and FCP-20 groups. The serum antibody titers against NDV and other biochemical parameters did not differ among the treatment groups.

\section{Intestinal Ecology of Broilers}

The selected bacterial populations in the intestine are presented in Table 6. There was no difference in the numbers of bacteria enumerated in ileum and caecum. The villi height was higher $(p \leq 0.05)$ in the duodenum of FCP-20 than that of CONT and FCP-15 birds (Table $7)$. There was a tendency $(p=0.07)$ that birds in FCP-15 group had a shorter jejunal villi height than FCP-20 and CONT birds. In ileum, the villi height was lower $(\mathrm{p} \leq 0.05)$ in FCP-20 than in CONT and FCP-15 birds.

Table 4. Performances and internal organs relative weight of broiler chickens

\begin{tabular}{|c|c|c|c|c|c|c|}
\hline \multirow{2}{*}{ Variables } & \multicolumn{4}{|c|}{ Treatment groups } & \multirow{2}{*}{ SE } & \multirow{2}{*}{$\mathrm{p}$ value } \\
\hline & CONT & FCP-10 & FCP-15 & FCP-20 & & \\
\hline \multicolumn{7}{|l|}{ BW gain (g/bird) } \\
\hline Day 22-28 & $247^{b}$ & $327^{a}$ & $310^{a}$ & $324^{\mathrm{a}}$ & 11.8 & $<0.01$ \\
\hline Day 29-38 & 513 & 615 & 550 & 534 & 33.7 & 0.20 \\
\hline Day $22-38$ & $760^{\mathrm{b}}$ & $942^{\mathrm{a}}$ & $860^{\mathrm{ab}}$ & $858^{\mathrm{ab}}$ & 34.0 & 0.01 \\
\hline \multicolumn{7}{|l|}{ Feed intake (g/bird) } \\
\hline Day $22-28$ & 423 & 468 & 478 & 489 & 26.4 & 0.35 \\
\hline Day 29-38 & $832^{c}$ & $977^{\mathrm{b}}$ & $1159^{a}$ & $1073^{\mathrm{ab}}$ & 43.7 & $<0.01$ \\
\hline Day 22-38 & $1256^{c}$ & $1445^{b}$ & $1637^{a}$ & $1562^{\mathrm{ab}}$ & 54.9 & $<0.01$ \\
\hline \multicolumn{7}{|l|}{ FCR } \\
\hline Day 22-28 & 1.75 & 1.43 & 1.54 & 1.50 & 0.09 & 0.12 \\
\hline Day 29-38 & $1.64^{\mathrm{b}}$ & $1.60^{\mathrm{b}}$ & $2.13^{\mathrm{a}}$ & $2.05^{\mathrm{a}}$ & 0.12 & 0.01 \\
\hline Day $22-38$ & $1.66^{\mathrm{bc}}$ & $1.53^{c}$ & $1.91^{\mathrm{a}}$ & $1.83^{\mathrm{ab}}$ & 0.07 & 0.01 \\
\hline \multicolumn{7}{|c|}{ Internal organ weight (\% live BW) } \\
\hline Heart & 0.52 & 0.42 & 0.50 & 0.53 & 0.03 & 0.13 \\
\hline Liver & 2.95 & 2.90 & 2.62 & 2.71 & 0.22 & 0.67 \\
\hline Proventriculus & 0.61 & 0.60 & 0.55 & 0.61 & 0.04 & 0.74 \\
\hline Gizzard & 1.88 & 1.71 & 1.76 & 1.69 & 0.11 & 0.64 \\
\hline Duodenum & 0.81 & 0.67 & 0.67 & 0.83 & 0.08 & 0.39 \\
\hline Jejunum & 1.38 & 1.33 & 1.25 & 1.37 & 0.11 & 0.81 \\
\hline Ileum & 1.40 & 1.37 & 1.28 & 1.25 & 0.10 & 0.66 \\
\hline Pancreas & 0.36 & 0.32 & 0.30 & 0.34 & 0.03 & 0.46 \\
\hline Caeca & 0.41 & 0.43 & 0.40 & 0.39 & 0.03 & 0.80 \\
\hline Spleen & 0.18 & 0.10 & 0.16 & 0.12 & 0.03 & 0.25 \\
\hline Thymus & 0.33 & 0.23 & 0.32 & 0.30 & 0.04 & 0.35 \\
\hline Bursa of fabricius & 0.08 & 0.06 & 0.06 & 0.06 & 0.01 & 0.36 \\
\hline Abdominal fat & $1.12^{\mathrm{a}}$ & $1.25^{\mathrm{a}}$ & $0.96^{\mathrm{ab}}$ & $0.68^{\mathrm{b}}$ & 0.13 & 0.04 \\
\hline
\end{tabular}

Note: Means in the same row with different superscripts differ significantly $(\mathrm{p} \leq 0.05)$.

CONT: maize-soybean-meal-based finisher diet, FCP-10: finisher diet containing 10\% FCP, FCP-15: finisher diet containing 15\% FCP, FCP-20: finisher diet containing 20\% FCP, FCP: fermented cassava pulp, BW: body weight, SE: standard error, FCR: feed conversion ratio 


\section{Carcass and Meat Characteristics of Broilers}

The carcass cuts and meat colours of broilers are presented in Table 8 . The relative weight of wings was higher $(p \leq 0.05)$ in FCP-20 broilers than in FCP-10 and
FCP-15 broilers, but similar to CONT broilers. The relative weight of eviscerated carcass and other commercial cuts did not differ across the treatment groups. Table 8 also shows that FCP-15 and FCP-20 had higher $(\mathrm{p} \leq 0.05)$ $\mathrm{L}^{*}$ (lightness) values when compared to control. The

Table 5. Complete blood counts, serum antibody titers against NDV and biochemical parameters of broiler chickens

\begin{tabular}{|c|c|c|c|c|c|c|}
\hline \multirow{2}{*}{ Variables } & \multicolumn{4}{|c|}{ Treatment groups } & \multirow{2}{*}{ SE } & \multirow{2}{*}{$\mathrm{p}$ value } \\
\hline & CONT & FCP-10 & FCP-15 & FCP-20 & & \\
\hline \multicolumn{7}{|l|}{ Complete blood counts } \\
\hline Hemoglobin (g/dL) & 10.3 & 10.7 & 11.3 & 10.0 & 0.49 & 0.30 \\
\hline Erythrocytes $\left(10^{6} / \mu \mathrm{L}\right)$ & 2.53 & 2.54 & 2.72 & 2.35 & 0.10 & 0.13 \\
\hline Hematocrit $(\%)$ & 26.5 & 26.7 & 28.2 & 24.8 & 1.09 & 0.22 \\
\hline $\operatorname{MCV}(\mathrm{fl})$ & 106 & 106 & 104 & 107 & 1.49 & 0.74 \\
\hline $\mathrm{MCH}(\mathrm{pg})$ & 40.7 & 42.1 & 41.5 & 42.5 & 0.83 & 0.45 \\
\hline $\mathrm{MCHC}(\mathrm{g} / \mathrm{dL})$ & 38.9 & 40.0 & 40.0 & 40.3 & 0.88 & 0.66 \\
\hline Leukocytes $\left(10^{3} / \mu \mathrm{L}\right)$ & 66.5 & 67.2 & 75.2 & 69.1 & 4.92 & 0.60 \\
\hline Heterophils $\left(10^{3} / \mu \mathrm{L}\right)$ & 7.20 & 7.10 & 9.60 & 7.30 & 1.30 & 0.48 \\
\hline Eosinophils $\left(10^{3} / \mu \mathrm{L}\right)$ & 4.20 & 4.40 & 5.50 & 4.40 & 0.58 & 0.41 \\
\hline Lymphocytes $\left(10^{3} / \mu \mathrm{L}\right)$ & 55.1 & 55.7 & 60.1 & 57.4 & 4.12 & 0.83 \\
\hline Thrombocytes $\left(10^{3} / \mu \mathrm{L}\right)$ & 10.0 & 9.40 & 9.80 & 8.80 & 0.78 & 0.71 \\
\hline Antibody titer against NDV ( $\log _{2}$ GMT) & 2.60 & 2.60 & 3.00 & 2.60 & 0.52 & 0.93 \\
\hline \multicolumn{7}{|l|}{ Serum biochemical parameters } \\
\hline AST (U/L) & 155 & 187 & 204 & 204 & 19.2 & 0.27 \\
\hline ALT (U/L) & 1.60 & 1.81 & 1.00 & 1.35 & 0.39 & 0.51 \\
\hline Uric acid (g/dL) & 8.72 & 8.42 & 5.41 & 6.96 & 1.37 & 0.33 \\
\hline Creatinine $(\mathrm{g} / \mathrm{dL})$ & 0.05 & 0.08 & 0.10 & 0.07 & 0.02 & 0.15 \\
\hline Total triglyceride (g/dL) & $43.0^{\mathrm{b}}$ & $53.6^{\mathrm{ab}}$ & $63.3^{\mathrm{a}}$ & $64.3^{\mathrm{a}}$ & 5.28 & 0.04 \\
\hline Total cholesterol (g/dL) & 106 & 114 & 123 & 137 & 9.40 & 0.14 \\
\hline $\mathrm{LDL}(\mathrm{g} / \mathrm{dL})$ & 22.9 & 46.9 & 40.7 & 46.0 & 10.2 & 0.42 \\
\hline $\mathrm{HDL}(\mathrm{g} / \mathrm{dL})$ & 78.8 & 66.8 & 69.2 & 78.4 & 5.79 & 0.36 \\
\hline Total protein $(\mathrm{g} / \mathrm{dL})$ & 1.75 & 2.94 & 2.19 & 2.54 & 0.40 & 0.22 \\
\hline Albumin $(\mathrm{g} / \mathrm{dL})$ & 1.05 & 1.15 & 1.11 & 1.26 & 0.07 & 0.19 \\
\hline Globulin (g/dL) & 0.70 & 1.79 & 1.08 & 1.28 & 0.36 & 0.23 \\
\hline $\mathrm{A} / \mathrm{G}$ ratio & 1.77 & 0.88 & 1.51 & 1.30 & 0.39 & 0.44 \\
\hline
\end{tabular}

Note: Means in the same row with different superscripts differ significantly ( $\mathrm{p} \leq 0.05)$.

CONT: maize-soybean-meal-based finisher diet, FCP-10: finisher diet containing 10\% FCP, FCP-15: finisher diet containing 15\% FCP, FCP-20: finisher diet containing 20\% FCP, FCP: fermented cassava pulp, MCV: mean corpuscular volume, MCH: Mean corpuscular hemoglobin, MCHC: mean corpuscular hemoglobin concentration, NDV: Newcastle disease vaccine, GMT: geometric mean titer, AST: aspartate aminotransferase, ALT: alanine aminotransferase, LDL: low-density lipoprotein, HDL: high-density lipoprotein, A/G ratio: albumin to globulin ratio, SE: standard error.

Table 6. The selected bacterial populations in ileum and caecum of broiler chickens

\begin{tabular}{|c|c|c|c|c|c|c|}
\hline \multirow{2}{*}{ Variables } & \multicolumn{4}{|c|}{ Treatment groups } & \multirow{2}{*}{ SE } & \multirow{2}{*}{$\mathrm{p}$ value } \\
\hline & CONT & FCP-10 & FCP-15 & FCP-20 & & \\
\hline \multicolumn{7}{|l|}{ Ileum (log cfu/g) } \\
\hline Coliform & 8.39 & 8.00 & 7.63 & 7.71 & 0.65 & 0.84 \\
\hline Lactose negative-enterobacteria & 8.55 & 8.69 & 8.43 & 8.78 & 0.59 & 0.98 \\
\hline Enterobacteria & 8.83 & 8.77 & 8.61 & 9.14 & 0.57 & 0.92 \\
\hline $\mathrm{LAB}$ & 11.2 & 10.1 & 10.6 & 10.5 & 0.45 & 0.31 \\
\hline \multicolumn{7}{|l|}{ Caecum (log cfu/g) } \\
\hline Coliform & 8.81 & 9.00 & 9.48 & 9.54 & 0.30 & 0.27 \\
\hline Lactose negative-enterobacteria & 8.39 & 8.43 & 8.31 & 8.25 & 0.56 & 0.99 \\
\hline Enterobacteria & 9.03 & 9.25 & 9.61 & 9.60 & 0.27 & 0.38 \\
\hline LAB & 10.8 & 11.5 & 11.5 & 11.5 & 0.33 & 0.40 \\
\hline
\end{tabular}

Note: CONT: maize-soybean-meal-based finisher diet, FCP-10: finisher diet containing 10\% FCP, FCP-15: finisher diet containing 15\% FCP, FCP-20: finisher diet containing 20\% FCP, FCP: fermented cassava pulp, LAB: lactic acid bacteria, cfu: colony forming units, SE: standard error. 
Table 7. The intestinal villi height of broiler chickens $(\mu \mathrm{m})$

\begin{tabular}{|c|c|c|c|c|c|c|}
\hline \multirow{2}{*}{ Intestinal parts } & \multicolumn{4}{|c|}{ Treatment groups } & \multirow{2}{*}{ SE } & \multirow{2}{*}{$\mathrm{p}$ value } \\
\hline & CONT & FCP-10 & FCP-15 & FCP-20 & & \\
\hline Duodenum & $1155^{\mathrm{b}}$ & $1302^{\mathrm{ab}}$ & $1193^{b}$ & $1363^{a}$ & 53.9 & 0.03 \\
\hline Jejunum & 1308 & 1272 & 1129 & 1327 & 56.0 & 0.07 \\
\hline Ileum & $900.5^{\mathrm{a}}$ & $741.6^{\mathrm{bc}}$ & $827.6^{\mathrm{ab}}$ & $666.9^{c}$ & 37.1 & $<0.01$ \\
\hline
\end{tabular}

Note: Means in the same row with different superscripts differ significantly $(\mathrm{p} \leq 0.05)$.

CONT: maize-soybean-meal-based finisher diet, FCP-10: finisher diet containing 10\% FCP, FCP-15: finisher diet containing 15\% FCP, FCP-20: finisher diet containing 20\% FCP, FCP: fermented cassava pulp, SE: standard error.

Table 8. Commercial proportions and colour values of breast meats of broiler chickens

\begin{tabular}{|c|c|c|c|c|c|c|}
\hline \multirow{2}{*}{ Variables } & \multicolumn{4}{|c|}{ Treatment groups } & \multirow{2}{*}{ SE } & \multirow{2}{*}{$\mathrm{p}$ value } \\
\hline & CONT & FCP-10 & FCP-15 & FCP-20 & & \\
\hline \multicolumn{7}{|c|}{ \% live $\mathrm{BW}$} \\
\hline Eviscerated carcass & 64.5 & 65.1 & 65.4 & 63.5 & 0.83 & 0.41 \\
\hline \multicolumn{7}{|c|}{$\%$ Eviscerated carcass } \\
\hline Breast & 33.1 & 32.9 & 34.8 & 33.6 & 0.78 & 0.35 \\
\hline Thigh & 17.4 & 17.6 & 16.5 & 16.3 & 0.49 & 0.22 \\
\hline Drumstick & 15.6 & 15.7 & 15.2 & 15.3 & 0.35 & 0.76 \\
\hline Wing & $11.8^{\mathrm{ab}}$ & $11.4^{\mathrm{b}}$ & $11.2^{\mathrm{b}}$ & $12.0^{\mathrm{a}}$ & 0.19 & 0.03 \\
\hline Back & 22.1 & 22.5 & 22.3 & 22.8 & 0.47 & 0.79 \\
\hline \multicolumn{7}{|c|}{ Meat colour } \\
\hline $\mathrm{L}^{*}$ (lightness) & $49.1^{\mathrm{b}}$ & $51.0^{\mathrm{ab}}$ & $52.7^{a}$ & $52.5^{\mathrm{a}}$ & 1.01 & 0.05 \\
\hline$a^{*}$ (redness) & 9.27 & 9.40 & 9.87 & 8.13 & 1.19 & 0.77 \\
\hline $\mathrm{b}^{*}$ (yellowness) & 25.1 & 25.5 & 26.2 & 24.4 & 1.52 & 0.86 \\
\hline
\end{tabular}

Note: Means in the same row with different superscripts differ significantly $(\mathrm{p} \leq 0.05)$.

CONT: maize-soybean-meal-based finisher diet, FCP-10: finisher diet containing 10\% FCP, FCP-15: finisher diet containing 15\% FCP, FCP-20: finisher diet containing 20\% FCP, FCP: fermented cassava pulp, BW: body weight, SE: standard error.

significant difference was not seen in $\mathrm{a}^{*}$ (redness) and $\mathrm{b}^{*}$ (yellowness) of breast meats.

\section{DISCUSSION}

Inclusion of FCP up to $20 \%$ in the diets at the expense of maize had no detrimental impact on the weight gain of broilers. Indeed, feeding of $10 \%$ FCP resulted in a higher BW gain in broiler chicks. This finding was different from that of our previous work showing a retarded growth rate in broilers fed $16 \%$ A. charticolaFCP (Sugiharto et al., 2017a). These present data were also different from Khempaka et al. (2014) reporting that feeding Aspergillus oryzae-FCP at $20 \%$ reduced the final BW of broiler at 42 days of age. The latter authors inferred that higher fibre content in the diet containing greater FCP may limit the nutrient digestibility and retention and thus decrease growth capacity of broilers. Sugiharto \& Ranjitkar (2019) recently noticed a wide variation in the effect of fermented feed on growth performance of broilers. Such variation may be due to the differences in the contents of protein, fibre and other nutritional metrics in the fermented feeds that eventually affect the nutrient utilization by the chickens. It has previously been reported that feeding FCP at the level of $20 \%$ may limit feed intake in broilers as such high inclusion implied in bulkiness and low palatability (Khempaka et al., 2014). Conversely, our present data showed that FCP inclusion up to $20 \%$ increased the feed consumption in broilers. Moreover, the inclusion of $20 \%$ FCP in the rations did not exert deleterious effect on the FCR of broilers. The reason for the increased feed intake in the FCP fed broilers in the present study was not exactly known, but the more improved feed palatability and digestibility following two-stage fermentation (Shi et al., 2017) may consequently increase the feed intake in broilers. Feeding FCP had no detrimental effect on the internal organ relative weight of broilers. This suggested that FCP was able to support the normal development of the internal organs, which was comparable to maize. It was apparent in this study that abdominal fat content decreased with the increased inclusion of FCP in broiler diets. In the earlier study, Khempaka et al. (2009) showed a decreased abdominal fat content in broilers fed with dry cassava pulp. They suggested that fibre content in cassava pulp may inhibit the lipid biosynthesis in the liver and hence fat deposition in the abdomen area of chicks (Khempaka et al., 2009). In the present study, the bioactive metabolites in FCP (produced during fermentation) may also take a part in lowering the abdominal fat content in broilers as reported by Nie at al. (2015) when feeding fermented cottonseed meal to broilers.

The blood profile has long been used as an indicator of the physiological status in broiler chickens. In this current study, the complete blood counts were comparable across the experimental groups. This suggested that inclusion of FCP in broiler finisher diets supported 
the normal physiological conditions in broilers. Data in the present study showed that feeding FCP increased the level of triglycerides in serum of broilers. Study revealed the positive correlation between the serum triglyceride and abdominal fat deposition in broiler chickens (Fouad \& El-Senousey, 2014). However, our present finding showed differently, in which the decreased abdominal fat pad was accompanied by the increased level of serum triglyceride. The reason for the latter condition was not exactly known, but the increased supply of non-esterified fatty acid (NEFA) (due to the increase in adipose tissue lipolysis) for the production of triglyceride-rich lipoproteins such as very-low-density lipoprotein (VLDL)-triglycerides in the liver may be the reason (Keller \& Miles, 1991). Indeed, Nie et al. (2015) reported that feeding fermented cottonseed meal reduced abdominal fat content in broiler chickens, which may be due to the increased abdominal fat cell lipolysis.

There was no effect of dietary treatments on the microbial populations of broiler chickens. This present finding was different from our earlier data showing a decreased number of coliform bacteria in the ileum of broilers fed $16 \%$ cassava pulp fermented with the fungus A. charticola (Sugiharto et al., 2017a). However, the data found in the present study were in accordance with that of recently reported by Okrathok et al. (2018), in which dietary inclusion of up to $40 \%$ cassava pulp fermented with $A$. oryzae had no substantial effects on the numbers of Escherichia coli, Bifidobacterium and Lactobacillus spp. in the caeca of laying hens. Sugiharto \& Ranjitkar (2019) noticed that the effect of fermented feed is highly variable in term of the bacterial diversity in the intestine of broilers. The differences in the nature of fermented feeds, types of chickens, composition of diets and conditions during the experiments may underlie the inconsistent effect of fermented feed on intestinal bacterial population of broilers.

Birds in FCP-20 group had a higher duodenal villi height when compared with FCP-15 and CONT birds. This finding may therefore suggest that feeding FCP improved the absorptive capacity of the chicks. Data from the earlier study showed that feeding fermented feed (prepared with probiotics Lactobacillus acidophilus, B. subtilis, Bifidobacterium and Saccharomyces cervisiae) increased villi height of duodenum, jejunum and ileum of broilers (Naji et al., 2016). Unlike the duodenum, the villi height of ileum in FCP-10 and FCP-20 birds were lower as compared to that in CONT group. With the assumption that maximum absorption have occurred in the duodenum, the ileal villi of FCP fed birds has therefore less developed in this study. Note that the histology of intestine is closely associated with the intestinal function. Yamauchi et al. (2010) gave an example that when the chicks are fed a conventional feed, the absorption is mainly occurred in the proximal part of the intestine, and therefore the ileal villi are less developed compared to duodenal villi. The latter authors also noticed a hypertrophied ileal villi after the resection of jejunal pieces in broiler chickens. Overall, feeding the two-stage FCP did not interfere the functions of duodenum and jejunum as the main site for nutrient absorption, and thus the two-stage FCP may be safely used to partially reduce the proportion of conventional feedstuffs such as maize in broiler rations.

Carcass parts were not different among the treatment groups, except for the proportion of wings that were higher in FCP-20 compared to FCP-5 and FCP-10 birds. Yet, the proportion of wing in FCP-20 birds did not differ when compared with control. The rationale for the latter condition remains unelucidated in the present study. It has been shown in the present study that feeding FCP increased the $\mathrm{L}^{*}$ (lightness) values. This condition may negatively affect the consumer preference as the lighter meat is often attributed to the impaired quality of broiler meats such as pale, soft, and exudative-like condition. However, it seemed not the case in our current study since the colour values of breast meat from FCP fed broilers were still within the normal breast meat lightness. Note that the values of breast meat lightness $\left(\mathrm{L}^{*}\right)$ may be categorized into light $\left(\mathrm{L}^{*}>53\right)$, normal $\left(48<\mathrm{L}^{*}<53\right)$ and dark $\left(\mathrm{L}^{*}<46\right)$ (Qiao et al., 2001).

\section{CONCLUSION}

Dietary inclusion of two-stage FCP up to $20 \%$ at the expense of maize did not cause deleterious effect on the growth performance, haematological parameters, intestinal microbiology and carcass characteristics of broiler chickens. In fact, feeding two-stage FCP at a level of $20 \%$ reduced the abdominal fat content and increased duodenal villi height of broilers.

\section{CONFLICT OF INTEREST}

Authors clarify that there is no conflict of interest with any financial, personal, or other relationships with other people or organization related to the material discussed in the manuscript.

\section{ACKNOWLEDGEMENT}

The study was funded by Diponegoro University through non-tax state revenue ('PNBP'), no. 385-83/ UN7.P4.3/PP/2018, 17 May 2018. PT. Bayer Indonesia (Jakarta, Indonesia) is acknowledged for providing the B. subtilis concentrate.

\section{REFERENCES}

AOAC. 1995. Official methods of analysis of the association of analytical chemists, Washington DC, USA.

Bolton, W. 1967. Poultry Nutrition. MAFF Bulletin No.174. HMSO, London.

Fouad, A. M. \& H. K. El-Senousey. 2014. Nutritional factors affecting abdominal fat deposition in poultry: A review. Asian-Aust. J. Anim. Sci. 27:1057-1068. https://doi. org/10.5713/ajas.2013.13702

Huu, H. L. \& T. Khammeng. 2014. Effect of yeast fermented cassava pulp (FCP) on nutrient digestibility and nitrogen balance of post-weaning pigs. Livest. Res. Rural Dev. 26:8. http://www.lrrd.org/lrrd26/8/huu26149.htm

Keller, U. \& J. M. Miles. 1991. Growth hormone and lipids. Horm. Res. 36:36-40. https://doi.org/10.1159/000182186

Khempaka, S., W. Molee, \& M. Guillaume. 2009. Dried cassava pulp as an alternative feedstuff for broilers: Effect 
on growth performance, carcass traits, digestive organs, and nutrient digestibility. J. Appl. Poult. Res. 18:487-493. https://doi.org/10.3382/japr.2008-00124

Khempaka, S., R. Thongkratok, S. Okrathok, \& W. Molee. 2014. An evaluation of cassava pulp feedstuff fermented with $A$. oryzae, on growth performance, nutrient digestibility and carcass quality of broilers. J. Poult. Sci. 51:71-79. https://doi.org/10.2141/jpsa.0130022

Naji, S. A., I. F. B. Al-Zamili, Hasan, S. A. Jawad, \& J. K. M. Al-Gharawi. 2016. The effects of fermented feed on broiler production and intestinal morphology. Pertanika J. Trop. Agric. Sci., 39:597-607.

Nie, C., W. Zhang, W. Ge, Y. Wang, Y. Liu, \& J. Liu. 2015. Effects of fermented cottonseed meal on the growth performance, apparent digestibility, carcass traits, and meat composition in yellow-feathered broilers. Turk. J. Vet. Anim. Sci., 39: 350-356. https://doi.org/10.3906/vet-1410-65

Okrathok, S., P. Pasri, R. Thongkratok, W. Molee, \& S. Khempaka. 2018. Effects of cassava pulp fermented with Aspergillus oryzae as a feed ingredient substitution in laying hen diets. J. Appl. Poult. Res. 27:188-197. https://doi. org/10.3382/japr/pfx057

Qiao, M., D. L. Fletcher, D. P. Smith, \& J. K. Northcutt. 2001. The effect of broiler breast meat color on $\mathrm{pH}$, moisture, water-holding capacity, and emulsification capacity. Poult. Sci. 80:676-680. https://doi.org/10.1093/ps/80.5.676

Reyes, F. C. C., A. T. A. Aguirre, E. M. Agbisit Jr, F. E. Merca, G. L. Manulat, \& A. A. Angeles. 2018. Growth performances and carcass characteristics of broiler chickens fed akasya [Samanea Saman (Jacq.) Merr.] pod meal. Trop. Anim. Sci. J. 41:46-52. https://doi.org/10.5398/tasj.2018.41.1.46

Shi, C., Y. Zhang, Z. Lu, \& Y. Wang. 2017. Solid-state fermentation of corn-soybean meal mixed feed with Bacillus subtilis and Enterococcus faecium for degrading antinutritional factors and enhancing nutritional value. J. Anim. Sci. Biotechnol. 8:50. https://doi.org/10.1186/s40104-017-0184-2

SNI (Indonesian National Standard). 2006. Standard for broiler feed (SNI 01-3930-2006). National Standardization Agency of Indonesia, Jakarta, Indonesia.
Sugiharto, S., T. Yudiarti, I. Isroli, E. Widiastuti, \& F. D. Putra. 2017a. Effects of feeding cassava pulp fermented with Acremonium charticola on growth performance, nutrient digestibility and meat quality of broiler chicks. S. Afr. J. Anim. Sci. 47:130-138. https://doi.org/10.4314/sajas.v47i2.4

Sugiharto, S., T. Yudiarti, I. Isroli, E. Widiastuti, \& F. D. Putra. 2017b. Effect of dietary supplementation with Rhizopus oryzae or Chrysonilia crassa on growth performance, blood profile, intestinal microbial population, and carcass traits in broilers exposed to heat stress. Arch. Anim. Breed. 60:347-356. https://doi.org/10.5194/aab-60-347-2017

Sugiharto, S. \& S. Ranjitkar. 2019. Recent advances in fermented feeds towards improved broiler chicken performance, gastrointestinal tract microecology and immune responses: A review. Anim. Nutr. 5:1-5. https://doi.org/10.1016/j. aninu.2018.11.001

Utomo, D.B. 2012. Indonesian maize production and trading for feed. International Maize Conference: "Maize for Food, Feed and Fuel". Indonesian Agency for Agriculture Research and Development (IAARD), Ministry of Agriculture and Gorontalo Provincial Government in Gorontalo, Sulawesi, Indonesia, 22-24 November 2012.

Villegas, P.1987. Avian virus diseases laboratory manual. College of Veterinary Medicine. University of Georgia, Athens, Georgia, USA.

Weng, T. M., \& M. T. Chen. 2011. Effect of two-step fermentation by Rhizopus oligosporus and Bacillus subtilis on protein of fermented soybean. Food Sci. Technol. Res. 17:393-400. https://doi.org/10.3136/fstr.17.393

Wongputtisin, P., C. Khanongnuch, W. Kongbuntad, P. Niamsup, S. Lumyong, \& P. K. Sarkar. 2014. Use of Bacillus subtilis isolates from Tua-nao towards nutritional improvement of soya bean hull for monogastric feed application. Lett. Appl. Microbiol. 59:328-333. https://doi. org/10.1111/lam.12279

Yamauchi, K.-E., T. Incharoen, and K. Yamauchi. 2010. The relationship between intestinal histology and function as shown by compensatory enlargement of remnant villi after midgut resection in chickens. Anat. Rec. 293:2071-2079. https://doi.org/10.1002/ar.21268 